\title{
Similarity Between Turkish \& Akkadian Based on Rules of Inflective \& Agglutinative Languages
}

\author{
Elşad Allili \\ Institute of Human Rights \\ Institution of Linguistics, Baku, Azerbaijan AZERBAIJAN
}

Osman Çataloluk (Corresponding Author)

Department of Archeogenetics, Anthropology and Linguistcs, Balıkesir University, TURKEY

E-mail: cataloluk@yahoo.com

Doi:10.7575/aiac.alls.v.5n.4p.113

URL: http://dx.doi.org/10.7575/aiac.alls.v.5n.4p.113
Received: 06/06/2014

Accepted: 15/07/2014

\begin{abstract}
Akkadian, although a dead language, has left deep imprints on Semitic and some Indo-European languages, and has played an important role in the history of mankind. It is accepted as the ancestor of all the Semitic languages. Beginning from the era of Sargon I, it became the official language in a vast area from Anatolia to Egypt and to India. Akkadian was the "Lingua Franca" of the ancient world, and has passed on many words to other languages such as Persian, Sanskrit and Greek. Although, Assyriologists at present ignore it, the language spoken in the very early days of Akkad, in BCE XXVIII-XXIV, may have been an agglutinative language like today's Turkish or Magyar, rather than an inflective language like today's Arabic and all Syriac languages. Thus it may show parallelism with Turkish.
\end{abstract}

Keywords: Akkadian, Turkish, Inflective Language Rules, Agglutinative Language Rules

\section{GENERATION of AKKADIAN}

Although, Assyriologists at present ignore it, the language spoken in the very early days of Akkad, in BCE XXVIIIXXIV, may have been an agglutinative language like today's Turkish or Magyar, rather than an inflective language like today's Arabic and Syriac languages. According to Bertin G., Akkadian was a northern dialect of Sumer from which it derived some phonetic peculiarities $[1,2]$. Hincks E. suggested that the language of Southern Babylonia was, in fact, Akkadian [2, 24] whereas the majority of the earlier Assyriologists argued that the language spoken in Southern Babylonia was an agglutinative Turanic Sumero-Akkadian language [3, XIV]. For Sayce AH., the language of Southern Babylonia was Sumerian and that of Northern Babylonia was Akkadian. Sayce AH., also stressed the influence of Semitic languages on this agglutinative Akkadian [4, 11-12]. Simith G. classified the personal names occurred in the tablets of the Hammurabi Period (BCE 1800) as Elam, Kassite (Kassu), Sami and agglutinative Akkadian [5, 194]. This last is not what is known as Semitic inflective Akkadian of the Sargonic era, but is what may be called "pre early Akkadian" or "proto-Akkadian". Since the language of the first tablets ever found was Assyrian, regardless of their language all the tablets found in the following excavations was given the same name: "Assyrian" as they had some Semitic characters and was spoken in Babylonia. For a long time, no doubt, the knowledge of Babylonian and Assyrian remained very imperfect. The difficulty of the task that remained was still very great, for it was found that Babylonian and Assyrian were not exactly the same language, but differed from one another at least as much as two strongly marked dialects of the same speech. As a result, Akkadian is acknowledged to have two dialects i.e. Babylonian and Assyrian [3, XIII].

Since modern scholars of Assyriology do not mention the agglutinative characteristics of the pre early Akkadian, the impression tried to be given is of an inflective language. For example, in his book on pre early Akkadian grammar, Ignace G., did not mention its agglutinative characteristics [6, 179-180]. However, earlier scholars described pre early Akkadian as an agglutinative language. Yet there is a difference between pre early Akkadian and the later period Akkadian. Thus cuneiform scribes of later period Akkadian produced new words by adding prefixes and prepositions to the words and verb roots as they did to Sumerian. This paved the way for the change of the grammar and then of the meaning of such words. Examples will be below presented.

It is shown here how Akkadian took root bases from agglutinative languages such as Turkish and produced new words, through several examples. It has been shown that there is a huge amount of root basis in Akkadian. Sayce AH., for example, reported that Akkadian and Semitic languages have many loan words with double consonants derived from Turanic, Ugro-Altaian languages [7, 113].

The Akkadian verb "na-pāš-u”, "na-paš-tu” (pl.) - to breathe, to become wide, to inhale, to calm down and to relax,

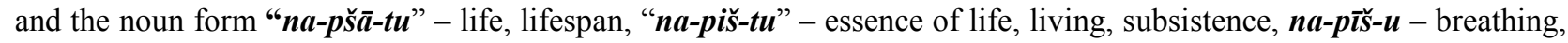
inhale, scent $[8,238-239]$ are clear examples of this. Here, "na" attaches to the root of the word as a preposition 
informing direction or/and proportion, "paš/piš" is the root basis, "u" is the masculine and "tu" is the feminine nominative case suffix. The "paš/pišs" root basis is used in very old and also in present day Turkish. In Akkadian the assimilation of the vowels $-\mathrm{a},-\mathrm{u},-\mathrm{i}$ and sometimes -e found in or in front of the word is usual. However the vowels -o, -ö, -ü, -1, ə (ä), generally found in cuneiforms, that could not be found in Akkadian texts are very common in Turkish. In old Turkish (OT) the words "pus/bus" and its synonyms could be used to mean spirit, life, or substance. Hence, there is a parallelism between Akkadian "paš/piš" and Turkish "pus/bus". In Northern Turkish dialects such as Tatar, the word "pus" is still used to mean spirit, life, pith, esprit and very substance. This word is much more conserved in Kipchak dialects. In old Kipchak texts "bus" and "pus" are used to mean to breathe and to inhale [9, 38; 216]. "pos" essence, very substance, was found in a $19^{\text {th }}$ century dictionary [10, 265-266]. In the Altaic dialect, this word is used to mean free, uncharged, liberated [10, 265-266]. The Turkish "boş" was also used to mean free, independent, unrestrained in OT $[11,113]$. Besides in Chuvash the verb "ves" - to fly, to become free, is a good example of this meaning in terms of semantic $[12,53]$. Attaching the prefix " $\boldsymbol{n} \boldsymbol{a}$ " and a nominative case suffix " $\boldsymbol{u}$ " (-tu) to a Turkish root base "paš/pišs", the Akkadian word "napistu" was produced. This new word was found in the famous name Ut(a) Napištum which is the prototype name for Noah in Sumerian Mythology. In ancient texts of Mesopotamia, names such as Ut(a) Napistum, Atrakharsis, and Ziisudra (Ksisutra) are common. The meaning of Ut(a) Napištum is warranted with the eternal life or awarded with an endless life. The word "uta/uti" means award or additional payment in old Akkadian [8, 430]. From the semantic perspective, this word is highly likely to show a parallelism with the "utli" - award, reward, payment, requital, and guerdon, premium which occur in OT and Uighur texts [11, 618]. The sentence from the ancient Turfan Text of China "Kim özitin üçün edgü uruğ saçsar jemä anang utlisin menigü ölmäz öz tängri yerintä bulir", which can be translated into English as follows; "Whoever disseminates the seeds of favor, he will be awarded immortality in the house of God in return", gives the exact meaning of the Akkadian "utli" [ibid]. It is worth pointing out that the "uti" in "ut(a) napištum" and the "utli" found in the Turfan Text quoted above have the same meaning. This also shows two old Turkic root bases in "ut(a) napištum, uti/utli" being an alleged and "piš/puş" the hidden root base.

Akkadian played an important role not only in transferring derivative words from borrowed root bases but also changed OT into other languages. By so doing, Akkadian had a deep impact on the development of Indo-European languages, so that many words thought to be Indo-European were, in fact, borrowed from Akkadian. For example, the root of "nam" (Persian), "nomo" (Latin), "name" (English) was borrowed from the Akkadian "nību/nimbu/nīpu" name; to name, to classify [8, 252], or from "nabû/nabīu" to name, to give name, to call, to invoke [13, Vol XIII, 3031]. These words occur in texts of the Old Akkadian (OAk), Old Babylonian (OB), and Old Assyrian (OAs) eras of Akkadian (2400-160 BC). Thus, although these words were presumed to be common to the Indo-European languages, it seems these Akkadian words were adopted by the Indo-European languages in the west and by Iranian and Hindu languages in the east. Similarly, the words "paradeisos" (Old Greek, OG), "paradisus" (Latin), and "Firdovs" (Persian) were derived from the Akkadian word "pardēsu" which means "enclosed garden" [8, 266]. Although scholars have claimed that since this word was found in the texts of New Babylonian (NB) period of Akkad (1000-700 $\mathrm{BC}$ ), it should be derived from the Old Persian (OP). This is doubtful since this period was a pre Achaemenid era and Persian dialects had not yet developed so as to have an impact on Akkadian. More importantly, this word is not found in the texts of the Achaemenid period of OP or in those of the later Zend (Avesta) period. This clearly proves that before the Achaemenid period (600 BC) Persian was not able to influence Akkadian and that "pardēsu" could not have been loaned to Akkadian from Persian. The English word "secret" and its Latin equivalent are also probably related to Akkadian word "secru" (concealed/closed up) and secretu/secratu (concealed woman) [8, 320]. The latter was used, but not often, as an adjective for the goddess in Akkadian.

Some Turkish words were also loaned to Indo-European languages via Akkadian. Thus, "barbar" which is supposed to be OG is probably derived from Akkadian word "barbaru" - wolf or leopard [8, 38]. It is a duplication of OT “börü, buri, bürü" - wolf [14, 50] (in some Turkic dialects "babir" - leopard). Akkadian has a lot of duplications and many of them were derived from loaned Turkic root words. For example, Akkadian duplicated word "bāqu/baqqu" mosquito, fly has the same meaning with the OT duplicated form "baqbaqbu" [8, 38]. In parallel with these words, OT has another word "baybayuk" which has the meaning "butterfly bird" [15, vol. III, 175]. Other than these words, there is also another word "mı̆̆g" - mosquito showing parallelism with and its duplicated forms

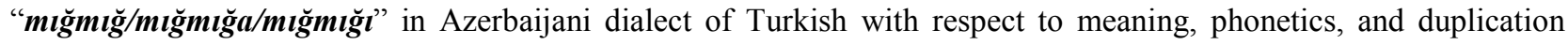
style [16,392]. Considering the b/m exchange in Akkadian and Turkish what this author says can be considered valid:

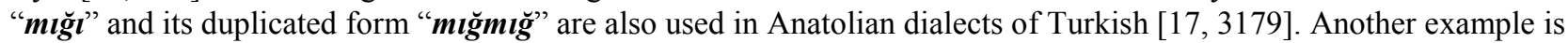
the Akkadian "zirzirru/čirčirru” (a kind of grasshopper) [18, Vol. I. 296]. It shows parallelism with "cırcır böceğil” (a kind of grasshopper) in Turkish in general and Anatolian Turkish dialects [17, 928] and "curcırama" (which occasionally means grasshopper) in the Azerbaijani dialect of Turkish [19, vol. I-412]. The Akkadian "dibdibbu/șipșippu" - clepsydra [8, 59] that describes dripping of water has an obvious relationship with the OT “dib/dip/tib/tip/tüb/tüp"-bottom [9, 61]. Some Akkadian reduplicated words are obviously equivalent to Turkish words. Parallelism between words through repetition of two root bases in two different language families indicates that this did not happen by chance but through close communication between the two languages at some time in their history.

Later Akkadian scribes produced new words by modifying the root bases. For example, by adding nominatives " $\boldsymbol{a}$ " and " $\boldsymbol{u}$ " to the Turkic verbal root word "sar - wrap, enwrap, encircle" [11, 488-489] they produced "asāru/esēru" to besiege [20, 116], and later akkadians "asirtu" - woman in captivity, "asīru" - prisoner of war [13, Vol. II. 331], 
"esēru" - to enclose, to confine; "ussuru" - to enslave, to take captive, "utassuru" - to become enclosed, "bît esēru" - prison, "esirtu" -concubine, "esīru" - prisoner, "esru" - captive, blocked [13, Vol. V. 334-338], "mēsiru” imprisonment, detainment [13, Vol. XII. 28]. Thus "esir" - prisoner of war/captive, supposed to be a loan word from Arabic, in fact, had such a derivation. However, it would not be possible to produce new Akkadian words if Semitic scribes implemented the rules of Ugro-Altaic grammar. Turkish grammar rules do not permit deriving new words from the root "sar." Since Turkish is a very conservative language, production of so many new words would take longer than the length of the Akkad Empire. But in the end these words would become Semitic but alien to Turkish and the sounds defining them would become alien too. Apparently the scribes in Akkad and Sumer chose this way of modifying the verbal roots to produce new words easily. At first these new words would be understood only by the scribes. As a result, early Akkadian lost its agglutinative character and turned into an inflective Semitic language. Although it is generally accepted by scholars that the Semitic words in Sumerian were of authentic origin, as in the case of "nefes-napis", the origin of such Semitic words can easily be traced. If the same would be applied to Turkish root words loaned to Akkadian and then passed to Arabic, what the linguists and scribes of those days had done could be understood better. Such derived words are plentiful in Akkadian, but it is not always easy to determine their origin. The most interesting and incomprehensible of all is "Akkad" itself. "Akkadu" means "country of the highlander" (aca is "high", acada " highlander") [21, 130]. Its root, "aka" - high, elevated, exalted, is probably related to the root word " $a \breve{g}(a k)$ " - get up, rise in OT $[11,16]$. As far as we know Semites were not of highlander in origin. Why then would Semites call themselves "highlander"? This jeopardized the early Assyriologists who prejudicially described the Akkadians as Semitic. Budge EA. has stated "The Akkadians descended from a mountainous country, but no part of Babylonia was mountainous. The inhabitants spoke an agglutinative dialect. Considerable discussion has existed between scholars as to whether the language should be called Sumerian or Akkadian, and also where Akkad was situated." [21, 130-131]. Really, if early Akkadians were of Semitic ethnicity, then, who were these highlanders? If they were not of Semitic ethnicity but were highlander, who were they and what was their ethnicity?

Several early Assyriologists have asserted that Akkadian was a Turanic language. As Rawlinson G. reported, the term "Kiprat-arbat" - four races, was frequently present in old Babylonian texts, and sometimes the languages spoken in the region were also described as "arba lisun" -four tongues. One of the four languages was a Turanic language, very similar to Turkish, Tatar and Magyar [22, Vol. I. 41-42]. Sayce AH., called the early form of this language "Sumerian" and claimed that in the very roots of Semitic civilization stands this Turanic Sumerian. He added that Semites borrowed their civilization, religious and judicial rules and mundane regulations from this people [2, 30]. Later researchers on Semitic and Old Testament rejected Sayce's claims as the fantasy of an amateur researcher. Once more the Semitic scholars protested. The Semitic philologist was more certain than ever that Assyrian decipherment was the folly of a few "untrained" amateurs and could safely be disregarded [2, 24-25]. Renan E., Halevi J., and others rejected AH. Sayce's opinions. Renan actually did not even accept that Semites could have been polytheist. Halevi denied the presence of Turanic Sumerian in Babylonia and claimed that Sumerian was an artificial language for writing. Others denied the idea that Semitics took their religion and culture from Turanians [3, XVI]. However, Rawlinson G., Bertin G., Conder CC., Hincks E., Norris E., Smith G., Oppert J., Vestergard N., Sayce AH., de Saulsy and others put forward evidence for the presence of Turanic (Ugro-Altaian) languages in Old Babylonian. In the light of all of this the borrowing of words and root bases from Turkish to Semitic and other old languages should be accepted.

The root word used most in Semitic Akkadian is the Turkic verb base "kes". Many forms of this, such as kâs - cut, break; $\boldsymbol{k} \ddot{a} \boldsymbol{s}$ - separate into small pieces [14, 72]; kas - shorten, abbreviate [9, 129]; $\boldsymbol{k e s}$ - to cut, chop, cut to piece [11, 302] are found in OT dictionaries. Derived from this base in Akkadian are: "kasāmu" - to cut, to chop; "kasāpu" - to break; "kas̄aru" - to block; "kāsimum" - butcher knife; "kāsiru" - barrage, castle; "kāsistu" - rodent, gnawer; "kasmu" - chopped tree or plant; "kassupu" - broken; "kašātu" - to cut off, chop down; "kismu" - cutting; "kissatu" - to gnaw [8, 150]. The words; "kasap, taksim, kısım, kasım, taksit, kısmet, aksam, maksam", which are supposed to be Arabic in origin, given the above examples, can easily be understood as borrowed from Akkadian and then passed on to Arabic.

While tracing the development of Akkadian, production of new words such as taksim, maksam by breaking the root words from into (transfix), can be seen. This, too, as it is said above, was only possible after implementation of artificial grammar rules. Turkic is an agglutinative language. In the process of production new words, the root of the word is not broken apart, and so the meaning of the root has never changed. As a result, the lexical power of the language is not changed or diminished even after many centuries. On the contrary, inflective languages implement new rules by changing or breaking the roots in order to produce new words. Halevi J's claim that Sumerian is an artificial language is based on the fact that both pre early Akkadian and Sumerian investigations were confined to court and temple inscriptions ${ }^{23}$. From his point of view, J. Halevi may be right. On the other hand, since court and temple inscriptions comprise newly produced words by implementing new and artificial rules developed by the scribes and women priests, it is not appropriate to call it as artificial before a detailed research ${ }^{24}$. Although the languages of old palaces and temples entail an artificial literary language grammar, this artificial writing benefitted greatly from the repertoire and dialects of the living languages of that time in that area.

In history, the languages of old palaces and temples were always different from the popular languages spoken by the people. The difference, however, between the two was sometimes too much. For example, there was a big difference between the official Turkic, used in the palaces of both Ottomans and Safavids and in their edicts, and the language used by ordinary people and wandering minstrels. So speaking from linguistic point of view, the Turkic spoken in the 
palace had different style and grammar rules from the living Turkic spoken by the ordinary people. Considering the conservative structure of Turkic, it can easily be comprehended how big the difference really is, compared to other languages. In this case, the language of palace, differing from the language of the people in style and grammatical rules, dramatically reveals. The same example can be given to illustrate the difference between the new Persian (NP) and middle Persian (MP). As is known, the NP was developed as the language of poetry and palace, in general, during the times of Samanids, Ghaznavids and the Seljuks. Comparing this language of literature with the oral Tati dialect, the Iranian people's speaking at that period of time reveals a very large difference between the two. At that time, for a person using Tati dialect of the MP, without having a lengthy education on literature, it was very difficult to understand NP. The same is true for Sumerian tablets too. In this case, one must admit that, due to its having a number of different dialects, Sumerian was a language of writing. This writing language and its different dialects depended on the lexical body, or vocabulary, of the language spoken by the people living in that time. Early Assyriology experts repeatedly pointed out that this language was a Turanic agglutinative language. The emesal (subtle taste) dialect which was the language of woman priests of Sumerian temples was highly different from the other Sumerian dialects. The interesting side of this is that some of the words used by the priests of woman were altered according to the rules of inflective languages. So, the new words emerged by playing on the roots of living Sumerian words. So, the language of the woman priests began to show the features of not entirety an agglutinative language, but a partly inflective one. This of course was an artificially developed event. Apparently this temple language, beginning with such an artificial development, seems first to have emerged in Southern Babylonia, then, evinced itself in the north $[23,70]$. This dialect, we can say, played a leading role, if not in the development of entire Akkadian, but at least in the development of a dialect which has taken Semitic shape in the subsequent period. Thus, by applying new rules to pre early Akkadian in the north, it was converted into an inflective language. As a result, Akkadian has earned the distinction of being the ancestor of all the known Semitic languages. No language remains as always the same in time, even the artificially emerging languages of palaces and temples, by applying new rules of literature and grammar undergo such changes. Obviously, addition of prefixes to the root words introduced into Sumerian and early Akkadian by the hands of scribes. These new grammar rules have served to economize writing on clay tablets. Unlike today, because of the difficulty in obtaining writing materials and the challenges posed by conditions for an education, writing was a demanding and a time consuming job of that time. As long as this course continued on, as in the case of the root verbs "sar" and "kes", root bases were broken down in the middle by transfixes to produce new words such as "esir, mesiru, kısim, taksim". This marks the slow transformation of Akkadian into a language that can be described as inflective and Semitic. As has been said above, it is indicative of the development of an artificial language. So, in the period of transformation, Akkadian, Arabic and other Semitic languages, while creating their own vocabulary and grammar, have benefited from the root words of Turkic and other Ugro-Altaic languages. These newly structured Semitic languages were not subjected to the rules of mathematical grammar as in Turkish, but have been subjected to regular inflective rules of their own differently. Indeed, these inflective rules strictly applied to Semitic languages such as Akkadian and Arabic. In fact, the genius hidden behind it is confidential. But it is a feature of human mentality. Then the new spelling rules (I. millennia BC) were prompted to apply to the origin of languages called "the IndoEuropean language family", however, the rules invented were not as punctual and regular as in Semitic languages. All in all Sanskrit and Persian filled their lexical vocabulary, influenced by ancient Turanic Languages (Ural-Altai), Akkadian, and other languages and have been subjected to a more complex grammatical development which were different from the Semitic languages. This process did not develop in a canonical fashion as in the early Semitic language. Sanskrit, as the language of religion, philosophy and mythology, actually possesses quite complex inflective rules. Sanskrit is the language which may perhaps have the most complicated inflective rules. If the claims of John Halevi for Semitic Akkadian and Arabic as being an artificial literary language are accepted to be true, then, the same should be applied to Sanskrit as well. But unlike Akkadian and Arabic, Sanskrit does not have durable grammatical rules.

In order to clearly show the loan words in Indo-European languages from Turkic and Akkadian, we need to look at some other issues. Given the comparative examples shown above it can be noticed that many Turkic root words and artificially produced many new words have also been borrowed by Arabic through Akkadian. Of course some Islamic terms of today, believed to have been borrowed from Arabic into Turkic, in fact, were the loan words from Akkadian. In a same manner, there are loan words in Akkadian from Turkic. The Akkadian Language took the Turkic words and changed them according to its own language rules to produce new words. For example, the Turkic verb root "kabar" (to bloat, to swell out, to swell, to tumefy, to rise, to blister, to upsurge, to arch; to be impudent / insolent; to sauce) was loaned to Akkadian, and then, it was used as an instrument in the emergence of new words such as akbar, cabbar, kibr, mutakabbir, icbar, cabir in Arabic. The development of these words will be shown below. But before this, let us investigate the process of emerging the word ahir/ahret which is supposed to be Arabic in origin.

\subsection{The History of the word "arka" 2}

Let us now investigate the emergence of "ahir/ahret" (end/hereafter) which is supposed to be Arabic in origin. Although "ahir/ahret" was borrowed from Arabic into presentday Turkish, it was earlier borrowed from Akkadian which had derived it from ancient Turkish by modification of "arkha/arka" into various forms. Examination of the early use of "arka" in Akkadian reveals this.

Various forms of "arka" occur in ancient inscriptions. These are "warka, arkâ, arki, arku, urki, urku" which mean, firstly, after, afterwards, and secondly, behind, in behind [13, Vol 2, 271]. 
Akkadian dictionaries show that "arka", was present in early Akkadian (EAk) (2500-2000 BC) and early Babylonian (EB) (2000-1600 BC) inscriptions and in Middle Babylonian (MB) (1600-1200 BC) texts also as "ark $\hat{a}$ " - later, next $[8,27]$. In ancient Turkish texts it occurs as "arka" [14, 13], "arga" [11, 53] and "arkha" [9, 10]. In phonetic transcriptions, "arka" has the meaning of behind, rear, or back side of the paddle. In Anatolian and Azerbaijan Turkish dialects this word is a helping temporal adverb, like after and afterward. Thus, the two EA meanings of "arka" have remained unchanged. In spite of the fact that the first meaning is not used very often, the second meaning of it is still used, time to time, as a helping adverb of time in both Anatolia and Azerbaijan. Semantically, "arka" has the same origin as "art". The extra - $\boldsymbol{k} \boldsymbol{a}$ is the affix specific to OT. In Akkadian grammar, there is no affix for word construction. So "arka" was constructed according to the rules of OT, but was first found in texts of the early Akkadian period. This word became subjected to various phonetic changes, was broken into parts to adjust it to rules of Akkadian grammar, and then used in the production of new derivatives in later Akkadian texts. However, the root "arkānis" - rear, then, in the end, in the back, back, back side, later, was subsequently loaned to Akkadian without change, and later found itself in EB (1000-700 BC) texts [8, 23]. Subsequently, "arkis" - back, behind, was merged with "taru (taraf-side, Arab.)" to produce the verb "arkis taru" - to turn back [8, 24]. The root of this word can be traced unchanged in Akkadian texts until the VII century B.C. whereas in some other texts, changes made to its root can be traced chronologically with the words in Semitic Lexicons as in given below;

arkānu (warkānum, barkānum, urkānum) - later on, afterward (EAk, EB) [13, Vol 2, 273].

arkat (warkat) - after (EB) [13, Vol 2, 274].

arkatam (warkatam, urkatam) - afterward, soon after, in the rear (EAk, EB) [ibid].

arkatu (warkatu, urkatu, barkatu) - rear side, rear area, back side, after (EAk, EB) [ibid].

arki (warka, warki) - after, in behind, rear (EAk, EB) [13, Vol 2, 278].

arkītam (warkìtam, urkìtam) - afterward, soon after (EAk, EB) [13, Vol 2, 281].

arkītu (warkītu, barkītu, urkītu) - continuation, following, future, second stationary point of the planet, rear, back side (EAk, EB) [ibid].

arku (irku) - long time, long term, long (EAk, EB) [13, Vol 2, 283].

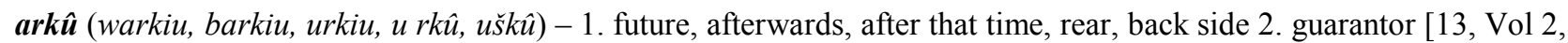
290] (EA, EAssy, EB) [13, Vol 2, 286].

arkîm (warkum, warku, ušk û) - afterwards,in the future (EB).

(in OT arqas - give support [11,54].)

We see the formation of $\mathrm{khr}(\mathrm{hr})$ by shifting of the consonants $\mathrm{r} / \mathrm{k}$ (metathesis) in the following examples:

ahrâtaš - in the future (Standard Babylonian; SB) [13, Vol 1, 193].

ahrâtu (ahriātu, ahrītu) - future; new generations (EB) [ibid].

ahrititis - in the future, hereafter [13, Vol 1, 194].

ahrūn - after [ibid]

aharr $\hat{u}$ - after (EB) [13, Vol 1, 170].

$\boldsymbol{a} \overline{\boldsymbol{a}} \overline{\boldsymbol{a}} \hat{u}^{92}$ - to be late [ibid].

ahăru (ahrâ) -to be behind, behind [8,7].

In this way the Turkish "arka/arkha" underwent a change of meaning via metathesis and turned to the Akkadian "ahra" and was used mostly as a temporal adverb. The - $\mathrm{r}$ sound metathesis in the middle of the word is a unique feature of Turkish. Kiprik-kirpik, yaprak-yarpak, köprü-körpü, yorgan-yogran, ördek-ödrek, of Turkish dialects are other examples. Starting from the EAk period, such changes in "arka/arkha" were frequently met and were characteristic of Akkadian. In fact, such changes can be traced in the roots of all words and their construction styles can be seen in Arabic, Jewish, and other Semitic languages. The word "ahäru" used in OB writings was an exception to this.

\subsection{The Progeny of "Kabar" 3}

As mentioned above, Turkish verb basis "kabar" was borrowed and participated in making a variety of new words in Akkadian, and then, loaned to Arabic and used to produce adjectives, such as "akbar, cabbar, kibir, mutakabbir, cabir, kibriya", and verbs derived from these adjectives. The meanings and various usages of the Turkish verb root "kabar" since the ancient times are as follows:

qabar - to swell, to bloat, fatten, puff up, and distend [11, 399].

kabar, kapar - to swell, to bloat out, and to become fluffy [14, 106].

kabar- to swell, to bloat out, to become puffed or fluffy [24].

$\boldsymbol{k a b a r}$ - to grow, to enlarge, to intensify, to become stronger [25, 133]. 
qabar - (1) to rise, to flow, to overflow; (2) to swell, to float; (3) (methaphorical) to resist, to swagger, to revolt, to upraise [19, Vol 3.9].

$\boldsymbol{k a b a r}$ - (1) to be proud of; (2) to swagger, to withstand, and to upraise [26, 447].

$\boldsymbol{k a b a r}$ - to rise, to swell; to swell, to bloat; to be proud of [27, 441].

kabargan- swelling of a part of the body, callus [11, 399].

kabartgan- exaggerating, swelling [ibid].

kabartı- swelling, flick, callus, and water bottle [19, Vol 3. 10].

The verb "kabar" in Turkish is produced according to the rules of Turkish grammar. Its root is "kap/gab" - blistered, swollen, a container, sack $[11,420]$ which is derived from an ancient Turkic adjective word. Finding of the same word with the same meaning in Sumerian is very interesting and it needs further investigation. The affix - ar in Turkish helps production of verbs from nouns/names. For example, - ot (grass) and - otar (to graze), - su (water) and -suvar (to water), - yaş (wet, moisture) and - yaşar (to become wet), and - baş (head) and -başar (to succeed). It should be mentioned that "qaba" [11,399] and "qapa" [11, 420] adjectives used to mean high and elevated in OT and show parallelism to Akkadian "gab'u" - height which cannot be considered as a coincidence [13, Vol VI, 6].

Several examples of Akkadian words which are related to the verb "kabar" in Turkish are:

gabarrahhu, kabarrahhu - rebellion (MB, Sum) [13, Vol VI, 1].

gabarû, gabrî - opponent (MB, NB) [13, Vol VI, 2].

gabbāru-strong (EAk) [13, Vol VI, 3].

gabru, gubburu - strong [13, Vol VI, 6].

gubburu - to subjugate, to subdue [13, Vol VI, 118].

gabru, gabbaru - strong, active; an adjective ascribed to the god Nebo/Nabu [18, Vol, I. 210].

kabartu - thickness (MB, LB) [8, 140].

kabartu, $\boldsymbol{k a b r u ̄ t u ~ - ~ s t r o n g ~ [ 1 8 , ~ V o l . ~ I , ~ 3 6 7 ] . ~}$

kabāru, habâru, kubburu - to become fat, heavy, thick, strong; to make heavy, thick, strong; to be constantly puffed up [13, Vol VI, 4].

kabâru - to be great, mighty, powerful [28, 388].

kabbaru - very big, very strong, almighty [18, Vol. I, 367].

$\operatorname{kabbaru}(\boldsymbol{m})$ - very thick [8, 140].

kabru - fattened, fat, thick, plump, large (MAk) [13, Vol IX, 22].

kabru - large [28, 389].

kabru-great, mighty [18, Vol. I, 367].

$\operatorname{kabru}(\boldsymbol{m}), \boldsymbol{k a b a r t u}(\boldsymbol{m})$ - thick, solid [8, 140].

kabrûtu - thickness (MB, LB) [ibid].

kabrûtu - greatness, bulkiness, strength [28, 389].

kabbartu - a part of the foot (MB, LB) [13, Vol IX, 18]

kibarru - boat made of inflated skin [13, Vol IX, 329].

kibrû - old and respected man [18, Vol IX, 336].

$\boldsymbol{k u} \boldsymbol{u} \bar{a} \boldsymbol{r} \boldsymbol{u}$-great, mighty [8, 140].

kubru - height, length [ibid].

Almost all the meanings of the Turkic verb base "kabar/qabar" such as swell, rise, inflate, be proud of, arrogance, stand before, go against, resist are found in Akkadian. Even the Akkadian name "kabbartu" (callus) found in the Old Babylonian texts has the same meaning as the Turkish counterpart "kabarti". Words produced from this verb base are; gabarrahhu, kabarrahhu - revolt, gabarû, gabrû - opponent/enemy, gabbāru, gabru, gubburu - strong, powerful, gubburu - outmatch, subdue, be dominant, be subject to, kabâru-large, puissant, strong, kabru - large, kabrûtu greatness, puissant.

The Turkish root base "kabar" was transformed into various Akkadian words such as "gabrû, gubburu, kabru, kabbartu, $\boldsymbol{k a b r u ̂ t u " ~ a c c o r d i n g ~ t o ~ t h e ~ i n f l e c t i v e ~ r u l e s ~ o f ~ A k k a d i a n . ~ A k k a d i a n ~ p r o d u c e d ~ m o r e ~ d e r i v a t i v e ~ w o r d s ~ f r o m ~}$ the same root base by applying inflective and internal inflective rules via transfixes. These include mukabbirru, muktabirru - to praise oneself, boaster, braggart [13, Vol XII, 181, 188], from the word "qabartgan" having several metaphorical meanings such as exaggerating, swelling, concocting which was similar to the word "kabar" in the OT.

Examples of other root words produced following internal inflective rules of Akkadian through transfixes from the Turkish root word "kabar" are: 
nakbartu - a kind of garment (MB) [13, Vol XIII, 180];

kabaru - ikbir, ikabbar - large,extended, be or become long, great, mighty [18, Vol. I, 366] ;

kabaru-uktebir - honor [18, Vol. I, 367].

As can be seen from these examples, Turkish root word "kabar/qabar" was loaned to Akkadian, through inflection and internal inflectional grammar rules, used often to produce nouns, verbs, and adjectives. As in the case of Nebo/Nabu (Gabbaru) some of these adjectives were used for the gods (Epithets). For example, the goddess Tiamat was known as "ummu khubur" the mother of abyss [13, Vol XII, 181]. In mythology, Tiamat was the goddess of oceans and was the wife of Apsu the god of oceans.

It is worth noting that "ikbir", “ikabbar", "uktebir" - large, broad, all-pervading, surrounding, strong, powerful, mighty, and honorable, found in Akkadian texts as the derivatives of "Kabaru" have fundamental ties with Arabic adjectives and nouns such as "akbar/ekber", "akabir/ekabir", "kabir", "kibar", "kibr", "kübra", "mutakabbir", "takbir", "takabbür". The same situation may extend to the Akkadian "gabbāru-gabru" - strong, powerful, effective, superior, subjugate, and dominant. Very likely this adjective took part in the production of adjectives and verbs such as "cabbar" - compelling, "cabir" - surpassing, victorious, "cebr" - compel, impel "ceberrut" - pitiless, cruel, "icbar" - coercion, compulsion, "mecbur" - compelled, obliged in Arabic. Since the consonant "g" was found in Akkadian and Aramaic, but not in Arabic, these words naturally had the sound value of - c (ج) in Arabic.

These examples show that Turkish root words played an important part in the formation of the earliest writing and religious literature in the history of mankind, that at the very core of some words of Semitic languages lay Turkish root words, and that Akkadian language used Turkish root words extensively.

Today Assyriology scholars have little or no knowledge of Turkish Grammar, whereas the first generation of experts who deciphered the Mesopotamian ideograms and cuneiform writings were familiar with the Ugro-Altaic languages. Early Sumerian and Akkadian texts contain words from Turkish, Altaic languages such as Finnish and other FinnoUgric languages. In early times, the languages of Mesopotamia took advantage of agglutinative Ugro-Altaic languages, and established a shared tradition of literature. In later periods, clerks and woman priests applied inflection rules to produce numerous new words. These were the heritage of the Semitic languages; many of them were borrowed by Indo-European languages and have been incorporated into the Turkish lexicon as new derivative words from Arabic.

\section{Acknowledgement}

I should thank to Dr. Frank Vella for his valuable helps, and patience on me.

\section{References}

Bertin G. (1888). Languages of the Cuneiform inscription. London. (Sumero-Akkadian Grammar).

Sayce AH. (1908). The Archeology of the Cuneiform Inscriptions. London.

Booth A J. (1902). The Discovery and Decipherment of the Trilingual Cuneiform Inscriptions.

Sayce AH. (1894). A Premier of Assyriology.

Smith G. (1884). The History of Babylonia. London.

Gelb I. (1955). Old Akkadian Inscriptions in Chicago Natural History Museum.

Sayce AH. (1872). Assyrian Grammar for Comparative Purposes. London.

A Concise Dictionary of Akkadian. (2000). Weisbaden.

Kıpçak Türkçesi Sözlüğ̈̈; (Qypchak Dictionary). (2007). Türk Dil Kurumu Yayınları. Ankara.

Verbitskiy PV. Словарь Алтайскаго и Аладакскаго Наръчий, Тюркскаго Языка (Dictionary of the Altai and Aladak Adverbs of the Turkic Language). (1884). Publication of Orthodox Missionary Assoc., Kazan.

Древнетюркский Словарь (The Old Turkic Dictionary). (1969). SSCB BA Leningrad.

Yegorov VG. Этимологический Словарь Чувашского Языка (Etymological dictionary of the Chuvash language ). (1964). Cheboksary.

The Assyrian Dictionary. The Oriental İnstitute of Chigago.

Caferoğlu A. (1968). Eski Uygur Türkçesi Sözlüğü (Old Uyghur Turkish Dictionary). İstanbul.

Mahmud Kaşqari, Divanü Lüğat-it Türk, Vol. IV., (2006). Azerbaycan Milli İlmler Akademisi Folklor İnstitüsü. Baku.

Azerbaycan Dialektoloji Lügati. (1999). Azerbaycan Milli İlimler Akademisi Nesimi Dil Enstitüsü; Türk Dil Kurumu Yayınları, Ankara.

Türkiye Halk Ağızları Derleme Sözlüğü. (1993). Türk Dil Kurumu Yayınları, 2. edit., Ankara.

William Muss-Arnolt. (1905). A Concise Dictionary of Assyrian Language. Berlin. 
Azerbaycan Dilinin İzahlı Lügati. (2006). Azerbaycan Milli İlimler Akademisi Nesimi Dil Enstitüsü. Bak1.

Mercer S. A. B. (1921). Assyrian Grammar with Chrestomathy and Glossary. London.

Budge E. A. (1880). History of Esarhaddon (Son of Sennacherib) King of Assyria, B.C. 681-668. London.

Rawlinson G. (1902). The Seven Great Monarchies of the Ancient Eastern World. New-York.

Haupt P. (1884). The Babylonian "Woman's Language". The American Journal of Philology, Vol. 5, No. 1. pp. 6884.

Türk Dil Kurumu "Dîvânu Lugâti't-Türk Veri Tabanı".

Dilçin C. (2009). "Yeni Tarama Sözlüğü” (New Tarama Dictionary). Türk Dil Kurumu Yayınları. Ankara.

Gülensoy T. (2007). “Türkiye Türkçesindeki Türkçe Sözcüklerin Köken Bilimi Sözlügü̆” Türk Dil Kurumu Yayınları. Ankara.

Radlov VV. (1893). “Opit Slovarya Tyurkskix Nareçiy (Опыт Словаря Тюркских Наречий) - Türkçe Lehçeler Sözlüğü (Turkic Dialectics Dictionary). Russian. V. IV. Sanktpetersburg.

Prince JD. (1908). Materials For a Sumerian Lexicon. Leipzig.

\section{Abbreviations}

OAk - Old Akkadian

OA - Old Assyrian

OB - Old Babylonian

MA - Middle Assyrian

MB Middle Babylonian

NA - New Assyrian

NB - New Babylonian

SB - Standart Babylonian

OT - Old Turkish

G - Greek

MP - Middle Persian 